\title{
Spontaneous release of angiotensin converting enzyme and interleukin $1 \beta$ from peripheral blood monocytes from patients with rheumatoid arthritis under a serum free condition
}

Makoto Goto, Michio Fujisawa, Akira Yamada, Tetsuro Okabe, Fumimaro Takaku, Minoru Sasano, Kusuki Nishioka

\begin{abstract}
Angiotensin converting enzyme (ACE) and interleukin 1 activities were assayed simultaneously in the serum free medium from the unstimulated peripheral blood monocytes from 32 patients with rheumatoid arthritis (RA), 11 patients with osteoarthritis, and 25 normal controls matched for age and sex. Angiotensin converting enzyme activity was raised in most (29/32) patients with $R A$ and interleukin 1 activity (most of which was interleukin 1 $\beta$ ) was enhanced in 11/32 patients with RA, while monocytes from only two patients with osteoarthritis, but from none of the controls, secreted a small amount of ACE alone in the culture condition. Monocytes from patients with early RA (disease duration $<3$ years) released significantly more ACE and interleukin 1 than those from late stage RA (disease duration $\geqslant 3$ years).
\end{abstract}

Rheumatoid arthritis (RA), a disease of unknown aetiology and worldwide distribution, is characterised by formation of non-necrotising granulomas, such as pannus and RA nodules rich in monocyte lineage cells, ${ }^{1}$ and a state of anergy to purified protein derivatives. ${ }^{2}$ These characteristics may be partly related to monocyte activation in RA. In patients with RA HLA-DR expression in synovial membrane macrophages is increased, ${ }^{3}$ interleukin 1 production by monocytes is enhanced, ${ }^{4}$ activities of $\mathrm{Fc}$ receptor and phospholipase $C$ in monocytes are increased, ${ }^{56}$ and there is increased biosynthesis of complement components by monocytes. ${ }^{7}$

Angiotensin converting enzyme (ACE) is a product of monocytes. Few, but controversial results on serum ACE activity in patients with RA have been published. Machin et al found no significant change in serum ACE levels of patients with Sjögren's syndrome associated with RA, systemic lupus erythematosus, or systemic sclerosis. ${ }^{8}$ Aoyagi et al reported decreased levels in RA, ${ }^{9}$ whereas Sheikh and Kaplan described increased ACE activity in serum samples from patients with RA and systemic lupus erythematosus. ${ }^{10}$ Therefore, we undertook this study to determine whether the serum level of ACE is increased, whether peripheral blood monocytes in $\mathrm{RA}$ release ACE and interleukin 1 spontaneously, and whether there is a correlation between them. The results showed that monocytes from patients with RA of less than three years' duration secrete ACE and interleukin 1 spontaneously, which is consistent with the hypothesis that there is monocyte activation in the early stage of RA.

\section{Patients and methods}

\section{PATIENT SELECTION}

Studies were carried out on 32 patients $(27$ female, five male) with definite or classical seropositive $\mathrm{RA}$, whose diagnosis was made according to the American Rheumatism Association criteria. ${ }^{11}$ Their ages ranged from 33 to 69 years (mean (SD) $54 \cdot 9(12 \cdot 4)$ ). The duration of disease in 19 patients with RA was less than three years (group A: $0.1-2.9$ years) and three or more years in 13 (group B: 3-25 years). Eleven patients (eight female, three male) aged $40-70$ years $(56 \cdot 3(10 \cdot 8))$ were radiographically diagnosed as having osteoarthritis. Twenty five healthy volunteers matched for age and sex served as controls. Most patients were treated with non-steroidal antiinflammatory drugs; in addition, 20 patients with RA were taking small doses of prednisolone $(\leqslant 10 \mathrm{mg} /$ day). No patients had been given second line antirheumatic drugs.

\section{ISOLATION OF PERIPHERAL BLOOD MONOCYTES} Heparinised blood $(10 \mathrm{ml})$ was obtained from each individual, and mononuclear cells were isolated by Ficoll density gradient centrifugation. ${ }^{12}$ After two washes in Hams F-10 nutrient medium (Flow Laboratories, Rockville, MD) at room temperature, the cells suspended in this medium were incubated in plastic Petri dishes $(60 \times 15 \mathrm{~mm}$; Falcon Labware, Oxnard, CA) at a concentration of $2 \times 10^{6}$ cells $/ \mathrm{ml}$ per dish for two hours at $37^{\circ} \mathrm{C}$ in $5 \% \mathrm{CO}_{2}$. After this incubation period the non-adherent cells were removed and the dishes rinsed with warm F-10 medium. The adherent cells were then incubated in F-10 medium. All cell counts were made in duplicate on cell cultures grown in parallel with those used for ACE measurements. For counting, cells were harvested in F-10 medium containing $0.8 \%$ lidocaine (Fujisawa Pharmaceutical Co, Osaka, Japan). ${ }^{13}$ The monocyte monolayers were washed twice with $4 \mathrm{ml} \mathrm{F-10}$ medium, then $2 \mathrm{ml}$ of $0.8 \%$ lidocaine was added to each dish, and the cells were incubated at $37^{\circ} \mathrm{C}$ for 15 minutes. F-10 medium $(2 \mathrm{ml})$ containing endotoxin-free $10 \%$ fetal bovine serum (Flow Laboratories) was then added, and the detached cells were collected and counted with a haemocytometer $\left(\sim 10^{5}\right.$ cells). Microscopic examination showed no residual cells in the dishes after treatment. The monocyte content of this cell preparation measured by nonspecific esterase activity was more than $90 \%{ }^{14}$ The protein content of the monocyte monolayers was assayed by the method of Lowry $e t$ al. ${ }^{15}$ All the media and fetal bovine serum used in this experiment were shown to be free 
from pyrogen by a conventional chromogenic Limulus test (Toxicolor test; Seikagaku-Kogyo, Tokyo). ${ }^{16}$

\section{ACE ACTIVITY ASSOCIATED WITH CELLS}

To measure ACE activity associated with cells the cells in monolayer cultures were removed with a rubber policeman, washed with F-10 medium, sonicated at $0^{\circ} \mathrm{C}$ for four 10 -second intervals, and partially solubilised in $0.5 \mathrm{ml}$ of $0.01 \mathrm{M}$ TRIS. $\mathrm{HCl}, \mathrm{pH} 7 \cdot 4$, in the presence of $0.5 \%$ Nonidat P-40 (Nakarai Chemicals, Kyoto, Japan), a non-ionic detergent used in the initial purification procedure for converting enzyme. ${ }^{17}$ Samples of $100 \mu \mathrm{l}$ were assayed for ACE activity.

\section{RELEASE OF ACE AND INTERLEUKIN 1 FROM MONOCYTES}

The monolayer of monocytes obtained from peripheral blood was incubated for 24 hours in 4 ml F-10 medium without fetal bovine serum to avoid possible monocyte stimulants. ${ }^{18}$ The collected medium was centrifuged for 20 minutes at $3000 \mathrm{rpm}$ to remove any suspended cells, and ACE and interleukin 1 activities were both assayed in the same supernatants.

\section{MEASUREMENT OF SERUM ACE ACTIVITY}

Serum ACE activity was determined spectrophotometrically by a modification of the method described by Cushman and Chung. ${ }^{19}$ One unit of ACE is defined as $1 \mathrm{nmol} / \mathrm{min}$ hippuric acid released from hippuryl-L-histidylL-leucine $(5 \mathrm{mmol} / 1$ initial concentration) at $37^{\circ} \mathrm{C}$.

\section{MEASUREMENT OF ACE ACTIVITY}

Angiotensin converting enzyme activity was measured by addition of angiotensin $I$ to the reaction mixture and measurement of the angiotensin II generated by radioimmunoassay. ${ }^{20}$ Bradykinin-potentiating peptide $B$, angiotensin I, angiotensin II, and bestatin were purchased from Protein Research Foundation, Osaka, Japan. Pepstatin A was kindly provided by Dr $\mathrm{T}$ Aoyagi, Institute of Microbial Chemistry, Tokyo, Japan. ${ }^{125} \mathrm{I}$-Angiotensin I and ${ }^{125} \mathrm{I}$-angiotensin II were obtained from New England Nuclear Co, Boston, MA. Other reagents were of analytical grade and were obtained from commercial sources.
MEASUREMENT OF INTERLEUKIN 1 ACTIVITY

Interleukin 1 activity was assayed by conventional thymocyte costimulation. ${ }^{1}$ An ultrapure human interleukin 1 standard was purchased from Genzyme Corporation (Boston, MA; sp act: $100 \mathrm{U} / \mathrm{ml}$ ).

The interleukin 1 activity in units per millilitre of supernatant samples was defined as the reciprocal of the dilution at which $50 \%$ of the maximum response was obtained. ${ }^{3}$ In one typical experiment one unit standard interleukin 1 gave $15000 \mathrm{cpm}$, and medium containing suboptimal phytohaemagglutin alone gave $150 \mathrm{cpm}$.

The neutralisation of interleukin 1 like activity was examined by preincubating the culture supernatant with varying concentrations (dilution 1:400-1:3200) of rabbit antihuman interleukin $1 \alpha$ or $\beta$ serum for two hours at $4^{\circ} \mathrm{C} .{ }^{21}$

\section{Results}

SERUM ACE ACTIVITY

Serum ACE levels (U/ml, mean (SE)) were $26 \cdot 8$ $(0.3)$ in RA, $24.9(1.6)$ in osteoarthritis, and $22.6(0.5)$ in controls (table 1$)$. There was no significant difference between these levels, though the mean serum level of ACE in the patients with RA was slightly higher than that of patients with osteoarthritis or controls. No significant difference in serum ACE level was observed between groups A (disease duration $<3$ years) and $B$ (disease duration $\geqslant 3$ years) among patients with RA (table 2).

RELEASE OF ACE INTO MEDIUM FROM MONOCYTES When the peripheral blood monocytes were maintained in serum free F-10 medium ACE activity appeared spontaneously in the media from patients with RA and osteoarthritis. The mean amount of ACE released from patients with RA was $\sim 500$ times more than that from patients with osteoarthritis per protein; no detectable amount of ACE was released from normal monocytes (table 1). The amount of ACE released from group A monocytes (disease duration $<3$ years) was four to five times more than that from group B monocytes (disease duration $\geqslant 3$ years) (table 2).

Drugs such as prednisolone may affect the release of ACE from monocytes. When patients in groups $\mathrm{A}$ and $\mathrm{B}$ were divided into two groups (those taking or not taking prednisolone), and the ACE release from monocytes compared, a slight, but insignificant decrease was noted in the patients treated with prednisolone in both

Table 1: Activities of angiotensin converting enzyme and interleukin 1 in arthritic patients. Values are means (SE) and (range)

\begin{tabular}{llll}
\hline & $\begin{array}{l}R A^{*} \\
(n=32)\end{array}$ & $\begin{array}{l}O A^{*} \\
(n=11)\end{array}$ & $\begin{array}{l}\text { Controls } \\
(n=25)\end{array}$ \\
\hline ACE $^{*}$ serum level $(\mathrm{U} / \mathrm{ml})$ & $26 \cdot 8(0 \cdot 3)$ & $\begin{array}{l}24 \cdot 9(1 \cdot 6) \\
(8 \cdot 9-69 \cdot 4)\end{array}$ & $\begin{array}{l}22 \cdot 6(0 \cdot 5) \\
(15 \cdot 5-55 \cdot 8)\end{array}$ \\
ACE culture supernatant (pg/20 min/mg protein/24 h) & $\begin{array}{l}(11 \cdot 6-43 \cdot 6) \\
110(12 \cdot 2) \dagger\end{array}$ & $\begin{array}{l}(0-5 \cdot 8) \\
(0-1469)\end{array}$ & 0 \\
Intracellular ACE (pg/20 min/mg protein) & $\begin{array}{l}23 \cdot 2(1 \cdot 2) \ddagger \\
(0-131)\end{array}$ & $\begin{array}{l}10 \cdot 3(2 \cdot 4) \\
(0-94 \cdot 2)\end{array}$ & 0 \\
IL-1* culture supernatant (U/ml) & $0 \cdot 5(0 \cdot 3) \ddagger$ & 0 & \\
\end{tabular}

${ }^{*} \mathrm{RA}=$ rheumatoid arthritis; $\mathrm{OA}=$ osteoarthritis; $\mathrm{ACE}=$ angiotensin converting enzyme; IL-1=interleukin 1.

$\uparrow \mathrm{p}<0.0001, \neq p<0.01$ compared with patients with $\mathrm{OA}$ or normal controls. 
Table 2: Effect of disease duration on the monocyte functions. Values are given as means (SLE) and (range)

\begin{tabular}{|c|c|c|c|c|c|c|c|}
\hline $\begin{array}{l}\text { Disease duration } \\
\text { (years) }\end{array}$ & $\begin{array}{l}\text { Number } \\
\text { of } \\
\text { patients }\end{array}$ & $\begin{array}{l}\text { Prednisolone } \\
\text { (mg/day) }\end{array}$ & $\begin{array}{l}E S R^{*} \\
(m m / h)\end{array}$ & $\begin{array}{l}\text { Released } \\
\text { ACE }{ }^{*} \dagger \\
(p \mathrm{~g} / 20 \mathrm{~min} / \mathrm{mg} \\
\text { protein } / 24 \mathrm{~h})\end{array}$ & $\begin{array}{l}\text { Intracellular } \\
\text { ACE } \\
(p g / 20 \mathrm{~min} / \mathrm{mg} \\
\text { protein })\end{array}$ & $\begin{array}{l}\text { Serum } \\
A C E \\
(U / m l)\end{array}$ & $\begin{array}{l}\text { Released } \\
I L-1^{*} \dagger \\
(U / m l)\end{array}$ \\
\hline Group $A<3(0.1-2 \cdot 9)$ & $\begin{array}{r}19 \\
9 \\
10\end{array}$ & $\begin{array}{l}4 \cdot 1(0 \cdot 1) \dagger \\
(0-10) \\
8 \cdot 1(0 \cdot 2) \\
(5-10) \\
0\end{array}$ & $\begin{array}{l}44 \cdot 0(1 \cdot 2) \\
(16 \cdot 5-99 \cdot 1) \\
45 \cdot 2(2 \cdot 6) \\
(16 \cdot 9-78 \cdot 8) \\
40 \cdot 3(2 \cdot 2) \\
(16 \cdot 5-99 \cdot 1)\end{array}$ & $\begin{array}{l}724 \cdot 3(16 \cdot 2) \ddagger \\
(282 \cdot 4-1469 \cdot 4) \\
655 \cdot 7(31 \cdot 9) \\
(282 \cdot 4-1200) \\
786 \cdot 4(32 \cdot 2) \\
(351 \cdot 6-1469 \cdot 4)\end{array}$ & $\begin{array}{l}29 \cdot 8(2 \cdot 1) \S \\
0-111 \cdot 1 \\
39 \cdot 9(4 \cdot 5) \\
(5 \cdot 3-111 \cdot 1) \\
20 \cdot 8(3 \cdot 9) \\
(0-47 \cdot 4)\end{array}$ & $\begin{array}{l}28 \cdot 0(0 \cdot 3) \\
(18 \cdot 7-28 \cdot 3) \\
27 \cdot 5(0 \cdot 4) \\
(23 \cdot 1-34 \cdot 7) \\
28 \cdot 5(0 \cdot 6) \\
(18 \cdot 7-38 \cdot 3)\end{array}$ & $\begin{array}{l}0.6(0 \cdot 1) \Phi \\
(0-2 \cdot 0) \\
0 \cdot 2(0 \cdot 1) \\
(0-0 \cdot 5) \\
0 \cdot 6(0 \cdot 1) \\
(0-2 \cdot 0)\end{array}$ \\
\hline Group $B \geqslant 3(3-25)$ & $\begin{array}{r}13 \\
11 \\
2\end{array}$ & $\begin{array}{l}5 \cdot 7(0 \cdot 1) \\
(0-10) \\
5 \cdot 9(0 \cdot 2) \\
(5-10) \\
0\end{array}$ & $\begin{array}{l}68 \cdot 0(2 \cdot 7) \\
(11 \cdot 2-132) \\
75 \cdot 3(2 \cdot 9) \\
(21 \cdot 6-132) \\
31 \cdot 2(9 \cdot 9) \\
(11 \cdot 2-51 \cdot 1)\end{array}$ & $\begin{array}{l}165 \cdot 4(9 \cdot 8) \\
(0-387 \cdot 2) \\
146 \cdot 1(10 \cdot 8) \\
(0-383 \cdot 6) \\
271 \cdot 4(56 \cdot 4) \\
(154-389 \cdot 2)\end{array}$ & $\begin{array}{l}13 \cdot 6(1 \cdot 8) \\
(0-92 \cdot 3) \\
14 \cdot 1(2 \cdot 3) \\
(0-92 \cdot 3) \\
10 \cdot 9(3 \cdot 1) \\
(4 \cdot 8-16 \cdot 9)\end{array}$ & $\begin{array}{l}28 \cdot 5(0.6) \\
(11.6-43.6) \\
27 \cdot 0(0.9) \\
(11.6-39 \cdot 2) \\
36.9(3 \cdot 4) \\
(30.2-43.6)\end{array}$ & $\begin{array}{l}0.1(0 \cdot 1) \\
(0-0.5) \\
0 \cdot 1(0 \cdot 1) \\
(0-0.5) \\
0\end{array}$ \\
\hline
\end{tabular}

${ }^{*} \mathrm{ESR}=$ erythrocyte sedimentation rate; $\mathrm{ACE}=$ angiotensin converting enzyme; IL-1 interleukin 1 .

TThese factors were released from monocytes cultured for 24 hours.

$\neq \mathrm{p}<0.001, \S \mathrm{p}<0.01$ compared with group $B$.

groups A (taking $v$ not taking prednisolone $655 \cdot 7$ (31.9), $\mathrm{n}=9, v 786 \cdot 4(32 \cdot 2), \mathrm{n}=10$, (mean (SE)) and B $(146 \cdot 1(10 \cdot 8), \mathrm{n}=11 v 271 \cdot 4$ $(56 \cdot 4), n=2)$. The depression of ACE release by prednisolone was not related to dose in either group. No significant correlation was observed between disease activity determined by erythrocyte sedimentation rate (ESR) and ACE release from monocytes.

Figure 1: Correlation between spontaneous release of $I L-1$ and $A C E$ from monocytes. Monocytes from patients with $R A, O A$, and from healthy controls were isolated and maintained in culture for 24 hours before assay. Both ACE activity and IL-I activities were detected in the same culture medium. There was a significant correlation $(r=0.62, p<0.0001)$ between them.

$A C E=$ angiotensin converting enzyme; IL-I = interleukin I; $R A=$ rheumatoid arthritis; $O A=$ osteoarthritis.

Figure 2: Relation between $A C E$ activity and disease duration. ACE release from $R A$ monocytes $(\mathbf{O}=$ patients taking NSAID alone; $\boldsymbol{\gamma}=$ patients taking NSAID and prednisolone) was plotted against disease duration. Monocytes from $R A$ of over three years' duration produced less than $400 \mathrm{pg} / 20 \mathrm{~min} / \mathrm{mg}$ protein/ $24 \mathrm{~h}$ ACE activity, while most (17/19) patients with a disease duration of less than three years released more than $400 \mathrm{pg} / 20 \mathrm{~min} / \mathrm{mg}$ protein/24 $h$.

$A C E=$ angiotensin converting enzyme; $N S A I D=$ non-steroidal anti-inflammatory drug; $R A=$ rheumatoid arthritis.
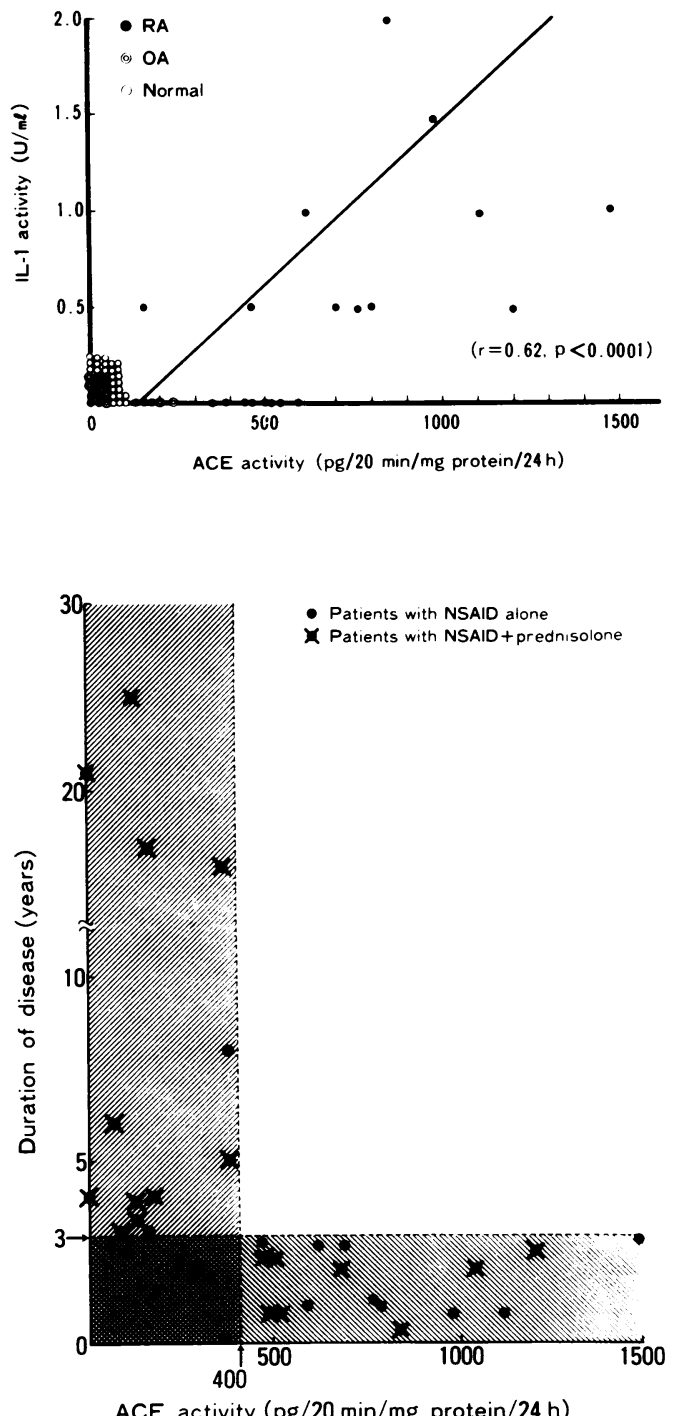

ACE activity $(\mathrm{pg} / 20 \mathrm{~min} / \mathrm{mg}$ protein $/ 24 \mathrm{~h}$ )
RELEASE OF INTERLEUKIN 1 INTO MEDIUM FROM MONOCYTES

Monocytes from patients with RA secreted interleukin 1 spontaneously, whereas all the 11 patients with osteoarthritis and 25 healthy individuals did not (table 1). Monocytes from two patients with osteoarthritis released a small amount of ACE without stimulation. All the interleukin 1 like activity was completely neutralised by rabbit antiserum interleukin $1 \beta$ antiserum, but not by anti-interleukin $1 \alpha$ antiserum. A significant correlation $(\mathrm{p}<0.0001)$ was observed between spontaneous release of interleukin 1 and ACE from RA monocytes, and from monocytes from all donors including normal controls, patients with RA, and patients with osteoarthritis (fig 1 ).

The interleukin 1 activity from group $A$ monocytes $(0.6(0.1) \mathrm{U} / \mathrm{ml})$ was significantly greater $(p<0.01)$ than that from group $B$ monocytes $(0 \cdot 1 \cdot(0 \cdot 1) \mathrm{U} / \mathrm{ml})$. Patients taking prednisolone released less interleukin 1 than those not taking prednisolone in group $\mathrm{A}$, but the difference was not significant (table 2). When ACE activity from RA monocytes was plotted against disease duration most (17/19) group A monocytes (disease duration $<3$ years), but none of the group B monocytes released more than $400 \mathrm{pg} / 20 \mathrm{~min} / \mathrm{mg}$ protein $/ 24 \mathrm{~h} \mathrm{ACE}$ (fig 2).

\section{ACE ACTIVITY IN MONOCYTES}

Although no ACE activity was detectable in monocytes of normal volunteers under our assay conditions, monocytes from patients with RA and osteoarthritis generated angiotensin II ranging up to $131 \mathrm{pg} / 20 \mathrm{~min} / \mathrm{mg}$ protein and $94 \cdot 2$ $\mathrm{pg} / 20 \mathrm{~min} / \mathrm{mg}$ protein respectively (table 1 ). The ACE activity of monocytes from patients with RA was inhibited by $95 \%$ when the cells were treated with $1 \mu \mathrm{g} / \mathrm{ml}$ cycloheximide for 72 hours in culture before assay. This indicated that ACE was synthesised in vitro and secreted rather than released from previous protein stores. The amount of monocyte ACE activity in group $A(29 \cdot 8(2 \cdot 1) \mathrm{pg} / 20 \mathrm{~min} / \mathrm{mg}$ protein) was about double that in group B (13.6 (1.8) (table 2).

Prednisolone may also affect the cellular content of monocyte ACE because intracellular 
ACE activity was slightly higher in patients treated with prednisolone than in those without such treatment in both groups A (39.9 (4.5) $v$ 20.8 (3.9) $\mathrm{pg} / 20 \mathrm{~min} / \mathrm{mg}$ protein; mean (SE)) and $B(14 \cdot 1(2 \cdot 3) v 10.9(3 \cdot 1)$. The higher intracellular ACE levels in the patients taking prednisolone may be partly explained by the prednisolone mediated suppression of ACE release. Two patients in group A were serially monitored for a few months. The activity of RA changed dramatically in one patient (No 1) after the administration of prednisolone (ESR fell from 57.9 to $27.6 \mathrm{~mm} / \mathrm{h}$ ), whereas the ESR in another patient (No 2) not taking prednisolone was almost stable (ESR $68 \cdot 1 \rightarrow 57 \cdot 9$ ). In patient No 1 both ACE activity $(500 \rightarrow 444 \mathrm{pg} / 20$ $\mathrm{min} / \mathrm{mg}$ protein/24 h) and interleukin 1 activity $(0.5 \rightarrow 0 \mathrm{U} / \mathrm{ml})$ released from monocytes decreased, but serum ACE level and intracellular ACE activity were unaffected. All the variables examined in this study were basically unchanged for patient No 2 .

\section{Discussion}

Much interest has been focused on the immune status in the circulation of patients with RA, primarily in relation to the immunopathogenesis of RA. There seems to be a decrease in the percentage and function of suppressor $T$ cells. ${ }^{24-26}$ In addition, monocytes in peripheral blood are activated and show an increased number of IgG Fc receptors, ${ }^{5}$ increased prostaglandin and phospholipase C synthesis, ${ }^{6}$ and greater phagocytic activity. ${ }^{27}$ Interleukin 1 and ACE are also products of activated monocytes. ${ }^{420}$ Our study showed that monocytes of the peripheral blood produce and release increased amounts of ACE and enhance the release of interleukin 1 in patients with RA, especially those in the early stages of $\mathrm{RA}$, like those with sarcoidosis. ${ }^{20} 28$

Most interleukin 1 like activity in the serum free culture supernatant, though its level was low, may be interleukin $1 \beta$, because this interleukin 1 like activity was completely neutralised by anti-interleukin $1 \beta$, but not by anti-interleukin $1 \alpha$ antiserum and $\sim 10 \mathrm{ng} / \mathrm{ml}$ interleukin $1 \beta$, but a negligible amount of interleukin $1 \alpha$ was detected by enzyme linked immunosorbent assay (ELISA) using recombinant human interleukin $1 \alpha$ or $\beta$ and antihuman interleukin $1 \alpha$ or $\beta$ (Goto et al, unpublished data). ${ }^{23}$

Monocytes from the patients with RA secreted ACE ( $~ 500 \mathrm{pg} / 20 \mathrm{~min} / 10^{5}$ cells $/ 24 \mathrm{~h}$ ) spontaneously in this study at a level comparable with that in sarcoidosis $\left(\sim 600 \mathrm{pg} / 20 \mathrm{~min} / 10^{5}\right.$ cells $/ 24$ h). ${ }^{20}$ The increased ACE activity of monocytes from patients with RA raises the question of whether other cell types distributed in the inflammatory lesions release ACE and interleukin 1 as do cells in sarcoidosis nodules and endothelium. ${ }^{20}{ }^{28}$ Experiments now in progress in our laboratory indicate increased spontaneous release of ACE and interleukin 1 from cells in both rheumatoid synovial membranes and nodules rich in macrophage-like cells (Goto et $a l$, unpublished data).

The spontaneous release of both ACE and interleukin $1 \beta$ from monocytes from patients with less than three years' duration of disease suggests a critical role of activated monocytes in the early stage of RA, though suppression of macrophage activation by prednisolone may also participate in the reduction of released ACE level in group B. The good correlation between ACE and interleukin $1 \beta$ secretion and the higher ievels of secretion of these two peptides in early RA rather than in late disease suggest (a) monocytes from early stage RA may be activated by unknown stimuli (or antigen), resulting in the release of interleukin $1 \beta$ and $A C E$, whereas those from late stage may be refractory to such stimuli, and $(b)$ secretion and production of these two substances may be similar in part. Regulation of activated monocytes through suppression of interleukin 1 release from monocytes and synovial cells has recently been thought to be beneficial for the control of RA. ${ }^{28-30}$

This is the first report of the spontaneous production and release of ACE and release of interleukin 1 from peripheral blood monocytes from patients in the early stage of RA. These results indicate a theoretical basis for the use of monocyte inhibitors in the treatment of early stage RA.

The rabbit antihuman interleukin $1 \alpha$ and $\beta$ were generous gifts of Dr Y Hirai of Otsuka Pharmaceutical Co, Tokushima, Japan.

1 Goto M, Sasano M, Yamanaka $\mathrm{H}$, et al. Spontaneous production of an interleukin-1-like factor by cloned rheumatoid synovial cells in long-term culture. 7 Clin Invest 1987 80: 786-96.

2 Malone D G, Wahl S M, Tsokos M, Cattell H, Decker J L, Wilder R L. Immune function in severe, active rheumatoid arthritis. A relationship between peripheral blood mononuclear cell proliferation to soluble antigens and synovial tissue immunohistologic characteristics. $\mathcal{f}$ Clin Invest 1984; tissue immun $1175-85$.

3 Miyasaka N, Sato K, Goto M, et al. Augmented interleukin-1 production and HLA-DR expression in the synovium of rheumatoid arthritis-possible involvement in joint destruction. Arthritis Rheum 1988; 31: 480-6.

4 Shore A, Jaglad S, Keystone E C. Enhanced interleukin 1 generation by monocytes in vitro is temporally linked to an early event in the onset or exacerbation of rheumatoid arthritis. Clin Exp Immunol 1986; 65: 293-302.

5 Katayama S, Chia D, Nasu H, Knutson D M. Increased Fc receptor activity in monocytes from patients with rheumatoid arthritis: a study of monocyte binding and catabolism of toid arthritis: a study of monocyte binding and catabolism of soluble

6 Bomalaski J S, Clark M A, Zurier R B. Enhanced phospholipase activity in peripheral blood monocytes from patients with rheumatoid arthritis. Arthritis Rheum 1986; 29: 312-8.

7 De Ceulaer C, Papazoglou S, Whaley K. Increased biosynthesis of complement components by cultured monocytes, synovial fluid macrophages and synovial membrane cells from patients with rheumatoid arthritis. Immunology 1980; 41: 37-43.

8 Machin N D, Chard M D, Paice E W. Serum angiotensin converting enzyme in Siögren's syndrome: a case report and
study of 21 further cases. Postgrad Med $\mathcal{F} 1986 ; 60: 270-1$.

9 Aoyagi T, Wada T, Tanaka T, et al. Decreased serum levels of various hydrolytic enzymes in patients with rheumatoid arthritis. Biochem Int 1984; 8: 529-35.

10 Sheikh I A, Kaplan A P. Assessment of kininases in rheumatic diseases and the effect of therapeutic agents. Arthritis Rheum 1987; 30: 138-45.

11 Ropes M W, Bennett G A, Cobb S, Jacox R, Jessar R A. 1958 Revision of diagnostic criteria for rheumatoid arthritis. Bull Rheum Dis 1958; 9: 175-6.

12 Boyum A. Isolation of mononuclear cells and granulocytes from blood. II. Isolation of mononuclear cells by one centrifugation, and of granulocytes by combining centrifugation and sedimentation at $1 \times \mathrm{g}$. Scand $\mathcal{f}$ Clin Lab Invest 1968; 21 (suppl 97): 77 89 .

13 Nathan C F, Asofsky R, Terry W D. Characterization of the nonphagocytic adherent cell from the peritoneal activity of normal and BCG-treated mice. $\mathcal{f}$ Immunol 1977; 118: 1612-2

14 Li C Y, Lam K W, Yam L T. Esterases in human leukocytes. 7 Histochem Cytochem 1977; 21: 1-12.

15 Lowry O H, Rosebrough N J, Farr A L, Randall R J. Protein measurement with the Folin phenol reagent. $\mathcal{F}$ Biol Chem 1951; 193: 265-75.

16 Obayashi T, Tamura H, Tanaka S. Endotoxin-inactivating 
activity in normal and pathological human blood samples. Infect Immun 1986; 53: 294-7.

17 Das M, Soffer R L. Pulmonary angiotensin-converting enzyme antibody. Biochemistry 1976; 15: 5088-94.

18 Hoffman M K, Mizel S B, Kirst J A. IL-1 requirement for B cell activation revealed by use of adult serum. F Immunol 1984; 133: 2566-71.

19 Cushman D W, Chung H S. Spectrophotometric assay and properties of the angiotensin converting enzyme of rabbit lung. Biochem Pharmacol 1971; 20: 1637-48.

20 Okabe T, Yamagata K, Fujisawa $M$, et al. Increased angiotensin-converting enzyme in peripheral blood monocytes from patients with sarcoidosis. $\mathcal{F}$ Clin Invest $1985 ; 75$ : $911-4$.

21 Goto $M$, Yoshinoya S, Miyamoto T, et al. Stimulation of interleukin $1 \alpha$ and interleukin $1 \beta$ release from human monocytes by cyanogen bromide peptides of type II collagen. Arthritis Rheum 1988; 31: 1508-14

22 Nishida T, Nishino N, Takano M, et al. cDNA cloning of IL-1 $\alpha$ and IL-1 $\beta$ from mRNA of U937 cell line. Biochem Biophys Res Commun 1987; 143: 345-52.

23 Tanaka K, Ishikawa F, Ohmoto Y, Hirai Y. Highly sensitive sandwich enzyme immunoassay for human interleukin $1 \beta$ (hIL-1 $\beta$ ) in urine using affinity-purified anti-hIL-1 $\beta$ Fab' peroxidase conjugate. Clin Chim Acta 1987; 166: 237-46.
24 Goto $M$, Miyamoto T, Nishioka $\mathrm{K}$, Uchida S. T cytotoxic and helper cells are markedly increased, and $T$ suppressor and inducer cells are markedly decreased, in rheur

25 Goto M, Miyamoto T, Nishioka K, Okumura K. Selective loss of suppressor $\mathrm{T}$ cells in rheumatoid arthritis patients: analysis of peripheral blood lymphocytes by 2 -dimensional flow cytometry. I R heumatol 1986; 13: 853-7.

26 Keystone E C, Gladman D D, Buchanan R. Impaired antigen-specific suppressor cell activity in patients with rheumatoid arthritis. Arthritis Rheum 1980; 23: 1246-51.

27 Steven M M, Lennie S E, Sturrock R D, Gemmell C G. Enhanced bacterial phagocytosis by peripheral blood monocytes in rheumatoid arthritis. Ann Rheum Dis 1984; 43: cytes in rheumatoid arthritis. Ann Rheum Dis 1984; 43:

28 Dinarello C A. Interleukin-1 and the pathogenesis of the acute phase response. $N$ Engl f Med 1984; 311: 1413-8.

29 DiMartino M J, Johnson W J, Votta B, Hanna N. Effect of antiarthritic drugs on the enhanced interleukin-1 (IL-1) production by macrophages from adjuvant-induced arthritic (AA) rats. Agents Actions 1987; 21: 348-50.

30 Arner E C, Darnell L R, Pratta M A, Newton R C, Ackerman N R, Galbraith A. Effect of antiinflammatory drugs on human interleukin-1-induced cartilage degradation. Agents Actions 1987; 21: 334-6. 